\title{
Five-year Cumulative Incidence of Obesity in Adults in Croatia: the CroHort Study
}

\author{
Sanja Musić Milanović ${ }^{1,2}$, Ana Ivičević Uhernik², Kristina Fišter¹, Sandra Mihel'2, Ana Kovač² and \\ Davor Ivanković ${ }^{1}$ \\ ${ }^{1}$ University of Zagreb, School of Medicine, »Andrija Štampar« School of Public Health, Department of Medical Statistics, \\ Epidemiology and Medical Informatics, Zagreb, Croatia \\ ${ }^{2}$ Croatian National Institute of Public Health, Zagreb, Croatia
}

\begin{abstract}
A B S T R A C T
The objective of this paper was to evaluate the 5-year incidence of obesity on a sample of 3229 adults and investigate the potential effect of several sociodemographic and lifestyle habits on weight change and obesity incidence in these individuals. The average annual rate of increase in the prevalence of obese adults between 2003 and 2008 was $10.60 \%$ for men and $11.08 \%$ for women. Analysis showed that development of obesity in 5-year period in women in Croatia is significantly positively associated with frequent consumption of »hidden « fats of animal origin and significantly negative with each higher education level. No significant predictor of obesity has been found in men. Obesity remains a serious health problem for the Croatian population; the alarming rates of excess body weight continue to increase. Preventive measures should urgently be undertaken.
\end{abstract}

Key words: obesity epidemic, 5-year incidence of obesity, annual obesity increase, sociodemographic and lifestyle characteristics, CroHort Study

\section{Introduction}

The statistics on obesity are appalling, with nearly half a billion of the world's population now considered to be overweight or obese. The problem does not only affect developed countries, as there is now a significant increase in overweight and obesity throughout the developing world. It is estimated that, at the beginning of this century, more people will die from complications of overnutrition than of starvation. Obesity is relatively common in Europe. Current prevalence data from individual national studies collated by the International Obesity Task Force (IOTF) suggest that obesity ranges from 10 to $20 \%$ for men, and 10 to $25 \%$ for women ${ }^{1}$. However, this prevalence has increased by about $10-40 \%$ in the majority of European countries in the past 10 years. The most dramatic increase has been in the UK, where it has more than doubled since 1980 . Obesity is caused by a combination of both genetic and environmental influences. The three main factors are genetic predisposition, disruption in energy balance, and environmental and social factors. The rapid increase in obesity, however, cannot be related purely to genetic change as the genetic pool changes slowly over thousands of years. In contrast, the environment has changed dramatically over the past few decades and it is this that accounts for the recent rise in obesity.

\section{Sample and Methods}

\section{Sample}

A sample of this study consisted of 3229 respondents. Men $(\mathrm{N}=1015)$ and women $(\mathrm{N}=2214)$ (18 years and over) living in Croatia, were included in both the Croatian Adult Health Survey (CAHS) 2003 and the follow-up Croatian Adult Health Cohort Study (CroHort) 2008. The sample of 3229 adults was investigated for the potential effect of several sociodemographic and lifestyle habits on weight change and obesity incidence. The sampling was random, multistage and included information about various sociodemographic and lifestyle (diet, exercise, binge drinking and smoking), characteristics. Both surveys were performed through personal visits. Data from the 3229 participants are analysed in the present 
TABLE 1

FIVE-YEAR INCIDENCE (2003-2008) OF OBESITY IN ADULTS IN CROATIA, DISTRIBUTION BY GENDER

\begin{tabular}{lccccc}
\hline & & 2003 & 2008 & \multicolumn{2}{c}{ Cumulative incidence } \\
\cline { 2 - 5 } & Age & BMI $<30 \mathrm{~kg} \mathrm{~m}^{-2}$ & BMI $<30 \mathrm{~kg} \mathrm{~m}^{-2}$ & $(\%)$ & $95 \%$ CI \\
\hline Men & -34 & 82 & 11 & 13.41 & $6.01-20.82$ \\
& $35-64$ & 402 & 39 & 9.70 & $6.80-12.60$ \\
& $65+$ & 273 & 16 & 5.86 & $3.12-8.63$ \\
Women & 757 & 66 & 8.72 & $6.71-10.72$ \\
& Total & 249 & 190 & 20.48 & $15.51-25.53$ \\
& -34 & 863 & 84 & 22.02 & $19.38-24.84$ \\
& $35-64$ & 474 & 325 & 20.49 & $14.34-21.25$ \\
\hline
\end{tabular}

BMI - body mass index, CI - confidence interval

work. Further details on this sample are described elsewhere ${ }^{2}$.

\section{Variables}

Self-reported body weight and height were used to calculate body mass index (BMI). BMI was calculated as weight in kilograms divided by the square of height in meters. Respondents whose BMI was $30 \mathrm{~kg} \mathrm{~m}^{-2}$ or higher were classified as obese.

The health behaviour information was based on self-reported information from respondents. For the present study, data on one key indicator from each of the four areas of health behaviour were chosen. The variable describing smoking prevalence was 'smoking index' based on several questions concerning duration of smoking in years and current smoking status, and then dichotomized as daily and occasional smokers and others. Among respondents who answered that they drink alcohol, binge drinking was positive if they drank six or more shots of spirits at once. People were asked what kind of fat they mostly used for food preparation at home. This variable was dichotomized as vegetable oil users and others. Information about leisure-time physical exercise was elicited in the following question: »How often do you engage in physical exercise in your free time for at least $30 \mathrm{~min}$ causing you to be at least mildly short of breath or to perspire?« Possible responses were: daily, 4-6 times per week, 2-3 times per week, once per week, 2-3 times per month, a few times a year or less, or »I cannot exercise because of an illness or disability «. The variable was divided into two categories: frequent exercise (2-3 times per week or more) and others.

\section{Statistical analysis}

The prevalences of respondents who had normal BMI in both 2003 and 2008, respondents who were overweight in both 2003 and 2008, and those who had normal BMI in 2003 but were overweight in 2008 were calcu- lated for each gender, as was the prevalence of obese respondents in 2008.

Five-year incidence was evaluated by repeated measurement in 2008 covering the same population sample. Calculation of the 5-year incidence of obesity was based on the respondents who answered the question about their height and weight and have a computed BMI in both studies. To calculate the change in obesity prevalence on an annual level, the following formula for average annual change was used ${ }^{3}$.

$$
\begin{aligned}
& s=(G-1) \cdot 100 \\
& G=\sqrt[n-1]{\frac{y_{n}}{y_{1}}}
\end{aligned}
$$

The first round surveyed 9070 persons older than 18 , whereof 6180 women and 2890 men. In the second round, 3229 of the 9070 respondents from 2003 agreed to new measurements and interviews in 2008, specifically 1015 men and 2214 women. Due to the differences in the number of CAHS 2003 and CroHort 2008 respondents, the former number first needed to be standardized to enable a comparison of the prevalences of obese persons.

\section{Coefficient $k=$}

$=\frac{\mathrm{Nb} .^{\#} \text { of responders in } 2008}{\mathrm{Nb} \text {. of responders in } 2003} \times \mathrm{Nb}$. of obese respondents

The logistic regression analysis (adjusted for age) was used to calculate OR for obesity in 2008 for respondents who were overweight both in 2003 and 2008 (BMI $\geq 25 \mathrm{~kg}$ $\mathrm{m}^{-2}$ ) and for respondents who had normal BMI in 2003 $\left(\mathrm{BMI}<25 \mathrm{~kg} \mathrm{~m}^{-2}\right.$ ), but were overweight in 2008 (BMI $\geq$ $25 \mathrm{~kg} \mathrm{~m}^{-2}$ ) compared to those respondents who maintained normal BMI $\left(\mathrm{BMI}<25 \mathrm{~kg} \mathrm{~m}^{-2}\right)$ both in 2003 and 2008.

All confidence intervals (CI) were calculated with $95 \%$ probability levels. Statistical analysis was performed using SPSS (version 14.01; License: Croatian National Institute of Public Health, SPSS ID: 729038).

\footnotetext{
\# Nb. - number
} 


\section{Results}

There were 3229 interviewees in total, thereof 1015 men and 2214 women. Of the 1105 surveyed men in CroHort 2008, 757 had in 2003 a BMI below $30 \mathrm{~kg} \mathrm{~m}^{-2}$. Repeated survey and calculation of BMI in 2008 showed that 66 among the 757 with normal or overweight body mass were categorized as new obesity cases. Of the 2214 surveyed women in CroHort 2008, 1586 had in 2003 a $\mathrm{BMI}$ below $30 \mathrm{~kg} \mathrm{~m}^{-2}$. Repeated survey and calculation of BMI in 2008 showed that 325 among the 1586 with normal or overweight body mass were categorized as new obesity cases. Between 2003 and 2008, $8.72 \%$ of new obesity cases among male respondents were recorded. The number of newly detected obesity cases decreased with age, with a maximum share recorded at the age below 35 , and minimum share in the population over 65 . In women too, the number of new obesity cases tended to drop with age, from $20.48 \%$ below 35 years of age, through $22.02 \%$ between ages 35 and 64 , to $17.72 \%$ among women older than 65 with a BMI $\geq 30 \mathrm{~kg} \mathrm{~m}^{-2}$. Overall 5-year (20032008 ) obesity incidence in women was $20.49 \%$ (95\% CI 18.51-22.55), which was significantly higher than in men (8.72\%; 95\% CI 6.71-10.72) (Table 1).

Over the five-year period, comparing year 2008 with 2003 , the prevalence of obese adults in Croatia grew for both genders, specifically to $65.59 \%$ in men and $69.09 \%$ in women. The average annual rate of increase in the prevalence of obese respondents over 18 in Croatia between 2003 and 2008 was $10.60 \%$ in men and $11.08 \%$ women (Table 2).

Table 3 shows predictive values of prognostic factors for obesity after said five years. Analysis was made of the direction and intensity of the connection between suspected demographic, behavioural and socioeconomic predictors of obesity recorded in the first round of CAHS 2003 survey and new obesity cases - persons who between 2003 and 2008 shifted from the category of normal body mass or overweight to the obese category. The analysis entailed multiple logistic regression which controlled all aggravating factors. Among the demographic indicators, sex and living environment proved to be significant predictors. Age - the most important risk factor for obesity in the 2003 cross-section study - proved to have no significant correlation with new cases of obesity over the monitored period (OR 2.45 in favour of women; 95\% CI 2.25-2.65; $\mathrm{p}<0.001$ ). Rural living setting contributed with a greater risk of new obesity cases, roughly the same in men (OR 1.25; 95\% CI 1.07-1.47) and women (OR 1.23; 95\% CI 1.10-1.43). Of all the analyzed behavioural and socioeconomic risks, no significant obesity predictors were found for men. Analysis detected two predictive risks for women, one from the group of nutritional behavioural risks - frequent consumption of cold cuts - which showed a significant positive correlation (OR 1.19; 95\% CI 1.09-1.34) with obesity in women who in the monitored period shifted from the category of normal or overweight to obese. The second significant predictor was higher degree of formal education which in women was associated with significantly lower probability of developing obesity (OR 0.75 ; 95\% CI 0.56-0.88) (Table 3).

\section{Discussion}

Between 2003 and 2008, 8.72\% new male obesity cases were documented, which is significantly less than the recorded female rate of $20.49 \%$. Obtained results can be explained by a time shift. In female obesity, a clear-cut age distribution is visible. The share of women aged 18-34 was significantly lower in comparison with the proportion of obese women at the age 35 and up. Five years later two thirds of respondents found themselves in the $35+$ category, at which point in time women experienced a sudden significant increment in developing obesity. Unlike women who saw $35-45$ as a turning point

TABLE 2

PREVALENCE OF OBESE ADULTS IN CROATIA IN 2003 AND 2008, DISTRIBUTION BY GENDER

\begin{tabular}{|c|c|c|c|c|}
\hline & \multicolumn{2}{|c|}{ Men, BMI $\geq 30 \mathrm{~kg} \mathrm{~m}^{-2}$} & \multicolumn{2}{|c|}{ Women, BMI $\geq 30 \mathrm{~kg} \mathrm{~m}^{-2}$} \\
\hline & CAHS data & $\begin{array}{c}\text { "Standardized « } \\
\text { number }\end{array}$ & CAHS data & $\begin{array}{l}\text { »tandardized « } \\
\text { number }\end{array}$ \\
\hline \multicolumn{5}{|l|}{2003} \\
\hline Number of respondents & 2143 & 457.22 & 6180 & 1161.72 \\
\hline $\mathrm{BMI} \geq 30 \mathrm{~kg} \mathrm{~m}^{-2}$ (number of respondents) & 442 & 205.22 & 1245 & 431.72 \\
\hline $\mathrm{BMI} \geq 30 \mathrm{~kg} \mathrm{~m}^{-2}$ (\% of respondents) & 20.63 & & 20.14 & \\
\hline \multicolumn{5}{|l|}{2008} \\
\hline Number of respondents & 1015 & 457.22 & 2214 & 1161.72 \\
\hline $\mathrm{BMI} \geq 30 \mathrm{~kg} \mathrm{~m}^{-2}$ (number of respondents) & 237 & 252 & 754 & 730 \\
\hline $\mathrm{BMI} \geq 30 \mathrm{~kg} \mathrm{~m}^{-2}$ (\% of respondents) & 25.33 & & 34.06 & \\
\hline Prevalence increse 2008-2003 (\%) & 65.59 & & 69.09 & \\
\hline Average annual rate of change (\%) & 10.60 & & 11.08 & \\
\hline
\end{tabular}

BMI - body mass index, CAHS - Croatian Adult Health Survey 
TABLE 3

PREDICTIVE VALUE OF PROGNOSTIC FACTORS FOR OBESITY OVER FIVE YEARS (2003-2008), DISTRIBUTION BY GENDER

\begin{tabular}{|c|c|c|c|c|c|c|}
\hline & \multicolumn{3}{|c|}{ Men } & \multicolumn{3}{|c|}{ Women } \\
\hline & OR & $95 \% \mathrm{CI}$ & $\mathrm{p}$ & OR & $95 \% \mathrm{CI}$ & $\mathrm{p}$ \\
\hline Age & 0.93 & $0.81-1.05$ & 0.234 & 0.93 & $0.83-1.04$ & 0.203 \\
\hline Animal fats & 0.93 & $0.60-1.44$ & 0.742 & 0.93 & $0.64-1.35$ & 0.712 \\
\hline Cured meat products & 0.81 & $0.56-1.18$ & 0.269 & 1.19 & $1.09-1.34$ & 0.028 \\
\hline Fruits and vegetables & 0.96 & $0.65-1.41$ & 0.830 & 0.96 & $0.67-1.44$ & 0.936 \\
\hline Alcoholic beverages & 0.89 & $0.56-1.41$ & 0.611 & 0.46 & $0.13-1.58$ & 0.215 \\
\hline Smoking & 0.93 & $0.84-1.79$ & 0.295 & 0.87 & $0.97-1.92$ & 0.079 \\
\hline Physical activity & 1.20 & $0.84-1.72$ & 0.311 & 1.07 & $0.79-1.44$ & 0.673 \\
\hline Education level & 1.02 & $0.80-1.30$ & 0.885 & 0.75 & $0.56-0.88$ & 0.022 \\
\hline Income & 0.97 & $0.77-1.22$ & 0.789 & 1.07 & $0.87-1.31$ & 0.551 \\
\hline Environment (urban/rural) & 1.25 & $1.07-1.47$ & 0.035 & 1.23 & $1.10-1.43$ & 0.033 \\
\hline
\end{tabular}

OR - odds ratio, CI - confidence interval

in terms of obesity, men had gone through a constant weight gain with age and were in no threat of five years causing a more prominent rise in the number of newly recorded obesity cases. There are few published studies comparable with the present study of 5 -year obesity incidence in Croatia. Australia detected $18.1 \%$ of new cases of obesity in the adult population over a 5 -year period of 1999-2004, which is comparable with the 5-year incidence of obesity in Croatia ${ }^{4}$. Another study conducted on a Greek population between 2001 and 2006 with virtually mirror image results, established a cumulative 5-year incidence of $21.8 \%$ in men and $11.9 \%$ in women ${ }^{5}$. The 5-year cumulative female incidence in Croatia numbering $20.59 \%$ by far surpasses the above Greek share of $11.9 \%$. Apparently, the Greek society is a more socially balanced one, providing Greek women with a protective factor against obesity ${ }^{5}$.

Over the 5 -year period, by comparing year 2008 with 2003, obesity prevalence in Croatia grew for both sexes, to $65.59 \%$ in men and $69.09 \%$ in women. The average annual rate of increase in obesity prevalence in Croatian respondents older than 18 between 2003 and 2008 was $10.60 \%$ for men and $11.08 \%$ for women. This high an annual increase rate for both sexes demands immediate public health intervention. Finding comparable data on the trends of obesity prevalence in other countries was virtually impossible for a relatively short period that is five years. Available data mostly showed secular change, though clear enough to warn about a galloping obesity problem in other populations as well. Developed countries have over the last decades prioritized obesity as one of the most urgent public health issues which has, despite the efforts to control the existing and prevent new cases, escalated ${ }^{7,8-10}$. Some countries have doubled their obesity share lately. Nearly one half of the adult US population were overweight and $15 \%$ obese by the end of 1970s. Today, three quarters of Americans are overweight, one third obese. Great Britain's dynamic echoes that of the USA. In 1980s, $40 \%$ of adults Brits were over- weight, less than $10 \%$ were obese. Presently, two thirds are overweight and $20 \%$ obese $\mathrm{ob}^{11-14}$.

Of all the analyzed behavioural and socioeconomic risks in men, no significant predictor of obesity was detected in the monitored period (2003-2008). An analysis of women yielded two predictive risks. Frequent consumption of cold cuts - a predictor from the group of nutritional behavioural risks - increased the risk by $20 \%$, while higher degree of formal education lowered it by $25 \%$ for women who went from normal or overweight to obese in the five years. This data is hardly comparable with the predictive risks of 5-year obesity incidence in other populations as past studies on the prediction of obesity had used as methods cross-sectional or longitudinal studies.

Health and social policies of obesity prevention are individually based in an attempt to educate people on the risks of obesity and help them internalize healthier habits in their everyday life. However, this approach does not address the fundamental issues of obesity - why people continue to adhere to unhealthy nutritional habits and sedentary life style, how habits are formed, why there is a social gradient of obesity and what the role of an acquired habit pattern of dealing with stress is. Though a change in life habits is easily achievable and, in fact, efficient on a personal level, social inequality must also be fought against among persons of good emotional status with an aptitude to manage and control one's own behaviour.

Only more socially balanced and equitable societies can on a collective level make a significant breakthrough in addressing the obesity epidemic. Change in health behaviour in Croatia over the last decade or so has probably been a result of an interaction of war events between 1991 and $1995^{15}$, the transition Croatia has been undergoing $^{16}$, as well as the changes taking place in the Croatian health care system ${ }^{17}$. All this affects not only globalization and urbanization in Croatia, but also health 
behaviour or, in other words, raises awareness about responsible health behaviour of adult Croatians. And responsible health behaviour in Croatia is more typically inherent in higher social strata. Women are more socially conditioned to become obese and run behavioural risks on the national, regional, continental, coastal, rural and urban levels. Men, probably more susceptible to the negative effects of globalization - especially westernization have not shown this clear a connection between their health behaviour and the social category they are in. Croatian women may be studied and approached as a more homogenous population than men, which means that female-oriented preventive measures should be designed depending on the socioeconomic group they target. Men, on the other hand, cannot be approached the same way. A recommended male-oriented preventive model is independent of their social category, includes behavioural risks and is applicable to all men regardless of their demographic and/or social conditioning.

From a public health aspect, key issue is whether health behaviour is socially conditioned. Attempts to disregard the effects of socioeconomic inequalities on the health through socioeconomic inequalities in health behaviour is, politically, a safe interpretation which supports and intensifies social, economic and health inequalities intra- and internationally. If health behaviour is not

\section{R E F E R E N C E S}

1. INTERNATIONAL OBESITY TASK FORCE, Global prevalence of adult obesity 2008, accessed 06.07.2011. Available from: URL: http:/ www.obesidade.info/estudos/About Obesity_(IOTF).pdf. - 2. IVIČEVIĆ UHERNIK A, VULETIĆ S, KERN J, DEČKOVIĆ-VUKRES V, MIHEL S; ERCEG M, PRISTAŠ I, Coll Antropol, 36 (2012) 3. - 3. ŠOŠIĆ I, Primijenjena statistika (Školska knjiga, Zagreb, 2004). - 4. BARR E, CAMERON A, SHAW J, ZIMMET P, The Australian Diabetes Obesity and Lifestyle Study: Five year follow-up (International Diabetes Institute, Australia, New South Wales, 2005). - 5. YANNAKOULIA M, PANAGIOTAKOS D, PITSAVOS C, LENTZAS Y, CHRYSOHOOU C, SKOUMAS I, Public Health Nutr 12 (2009) 36. - 6. WILKINSON R, PICKETT K, The Spirit Level: Why equality is better for everyone (Penguin Book, England, 2010). - 7. MOKDAD AH, MARKS JS, STROUP DF, GERBERDING JL, JAMA 291 (2004) 1238. - 8. FLEGAL KM, CAROLL MD, KUCZMARSKI RJ, JOHNSON CL, Int J Obes, 22 (1998) 39. - 9. DOBSON AJ, EVANS A, KUULASMA KA, Ann Med 30 (1998) 199. — 10. THOMSEN socially conditioned, public health policy and interventions, such as education focusing on health behaviour risks, will improve the health of the population, as well as significantly reduce health inequalities. This approach is recommended when designing a Croatian male obesity prevention program. If health behaviour is socially conditioned, then this health policy, supported by the well-known fact that people from lower social strata do not respond to traditional health education by sensitizing and informing the general population, will improve the health of the population but also additionally aggravate social inequalities in health. Traditional health education has not proven itself efficient. Moreover, lower socioeconomic strata do not seem to respond to it ${ }^{18}$. This finding should be borne in mind while designing a national female obesity prevention program as this study has proven, beyond any doubt, that the social component has both direct and indirect effects.

\section{Acknowledgements}

This article was prepared as part of the scientific project »Regionalism of cardiovascular behavioural risk factors - model of intervention « (108-1080135-0264) supported by the Ministry of Science, Education and Sports of the Republic of Croatia.

\section{S. Musić Milanović}

University of Zagreb, School of Medicine, "Andrija Štampar « School of Public Health, Rockefellerova 4, 10000 Zagreb, Croatia

e-mail:sanja.music@hzjz.hr

BL, EKSTROM CT, SORENSEN TL, Int J Obes Relat Metab Disord, 23 (1999) 693. - 11. OGDEN CL, CARROLL MD, CURTIN LR, MCDOWELL MA, TABAK CJ, FLEGAL KM, JAMA, 295 (2006) 1549. - 12. FLEGAL KM, CARROLL MD, KUCZMARSKI RJ, JOHNSON CL, JAMA, 288 (2002) 1723. - 13. INTERNATIONAL OBESITY TASKFORCE, Obesity in Europe (International Obesity TaskForce in collaboration with the European Association for the Study of Obesity Task Forces, London, 2002). - 14. WORLD HEALTH ORGANIZATION, Report of a Joint WHO/FAO Expert Consultation: Diet, nutrition and the prevention of chronic diseases (: WHO Tecnical Report Series no. 916. WHO, Geneva, 2002). - 15. POLAŠEK O, Eur J Epidemiol 21 (2006) 61. - 16. FIŠTER K, MCKEE M, BMJ, 331 (2005) 169. - 17. VONČINA L, DŽAKULA A, MASTILICA M, Health Policy 80 (2007) 144. - 18. MARMOT MG, ROSE G, SHIPLEY MJ, HAMILTON PJS, J Epidemiol Community Health, 32 (1978) 244. 


\section{5-GODIŠNJA KUMULATIVNA INCIDENCIJA DEBLJINE U ODRASLIH U HRVATSKOJ: CroHort STUDIJA}

\section{S A Ž E T A K}

Cilj je ove analize utvrditi prevalenciju i petogodišnju incidenciju debljine u Hrvatskoj te ustanoviti prediktivnu vrijednost prognostičkih čimbenika za debljinu nakon pet godina. Rezultati ukazuju da je u razdoblju od 2003 . do 2008. godine prevalencija osoba s debljinom u Hrvatskoj porasla u muškaraca za 65,59\%, a u žena za 69,09\%, što čini prosječnu godišnju stopu porasta od 10,60\% u muškaraca i 11,08\% u žena. Kumulativna incidencija odraslih osoba s debljinom u petogodišnjem razdoblju 2,5 puta je veća u žena (20,49\%) nego u muškaraca (8,72\%). Značajan prediktor debljine nastale u promatranom petogodišnjem periodu (2003.-2008.) nije nađen u muškaraca, dok prediktori nađeni u žena potvrđuju obrazac rizika iz 2003. godine, odnosno pozitivnu povezanost debljine i učestale konzumacije suhomesnatih proivoda te negativnu sa svakim višim stupnjem formalnog obrazovanja. Udio odraslih osoba s debljinom u porastu je unatoč stalnoj borbi protiv nje. Preventivne javnozdravstvene programe vezane uz problem debljine valjalo bi usmjeriti na važnost i posljedice učestale konzumacije "skrivenih « masnoća životinjskog porijekla. U muškaraca je moguće primjeniti jedinstveni model edukacije, dok su za žene potrebni specifični programi, prilagođeni njihovoj socijalnoj pripadnosti. 